\title{
The molecular epidemiology of respiratory viruses in military trainees in Iran
}

\author{
Ahmad Tavakoli ${ }^{1}$, Mohammad Hadi Karbalaie Niya ${ }^{2}$, Farah Bokharaei-Salim ${ }^{1}$, \\ Mohammad Farahmand ${ }^{3}$, Morteza Izadi ${ }^{4}$, Ruhollah Dorostkar ${ }^{5}$, Hossein Keyvani*1 \\ Received: 3 Sep 2018 \\ Published: 8 May 2019
}

\begin{abstract}
Background: Military populations are more prone to respiratory infections worldwide. There is a dearth of research about the role of viral pathogens in the etiology of respiratory infections in military trainees in Iran. Hence, we aimed to investigate the molecular epidemiology and clinical symptoms of respiratory viruses among this population.

Methods: This cross-sectional study was performed on 400 military trainees with symptoms of respiratory infection, referred to the military medical clinic center in the basic military training camp of the General Staff of the Armed Forces of the Islamic Republic of Iran. Nucleic acid extraction from the throat or nasopharyngeal swab samples was performed by an automated extraction system. The extracts were then analyzed by the CLART ${ }^{\circledR}$ PneumoVir array system for the detection of respiratory viruses.

Results: All military trainees were male, aged between 18 and 57 years (mean: 21.69 years). Sore throat (75.5\%), rhinorrhea $(63.2 \%)$, cough $(59.2 \%)$, fever $(59.2 \%)$, and nasal congestion (50.5\%) were amongst the most common symptoms. Overall, viral pathogens were detected in a total count of $124(31 \%)$. The most commonly detected viruses were rhinovirus $(7.2 \%)$, respiratory syncytial virus $A(7.2 \%)$ and influenza B virus $(6 \%)$

Conclusion: This study was an important first step for understanding the etiological role of viral pathogens in respiratory infection among military trainees population in Iran. Our results indicated that rhinovirus, respiratory syncytial virus A and influenza B virus are important viral pathogens causing respiratory infection in military trainees, respectively. However, further multi-center studies with larger sample size are strongly recommended to confirm our findings.
\end{abstract}

Keywords: Military trainees, Respiratory infection, Microarray, Iran, Viral infection

Conflicts of Interest: None declared

Funding: Iran University of Medical Sciences (Grant no. 26051)

\section{*This work has been published under CC BY-NC-SA 1.0 license.}

Copyright $($ Iran University of Medical Sciences

Cite this article as: Tavakoli A, Karbalaie Niya MH, Bokharaei-Salim F, Farahmand M, Izadi M, Dorostkar R, Keyvani H. The molecular epidemiology of respiratory viruses in military trainees in Iran. Med J Islam Repub Iran. 2019 (8 May);33:40. https://doi.org/10.47176/mjiri.33.40

\section{Introduction}

The role of respiratory infections as key causes of morbidity and mortality among military trainees is well-

Corresponding author: Dr Hossein Keyvani, keyvanlab@yahoo.com, keyvani.h@iums.ac.ir

1. Department of Medical Virology, Faculty of Medicine, Iran University of Medical Sciences, Tehran, Iran

2. Institute of Immunology and Infectious Diseases, Iran University of Medical Sciences, Tehran, Iran

3. Department of Virology, School of Public Health, Tehran University of Medical Sciences, Tehran, Iran

4. Health Research Center, Baqiyatallah University of Medical Sciences, Tehran, Iran

5. Applied Virology Research Center, Baqiyatallah University of Medical Sciences, Tehran, Iran recognized. Compared to the young healthy adults' population, military trainees undergoing basic military training

$\uparrow$ What is "already known" in this topic:

Some previous studies reported that adenoviruses, influenza viruses, human rhinoviruses, and coronaviruses are the predominant viruses detected in the military population. However, there is no report on the prevalence of respiratory viruses in the military population in Iran and even in the Middle East.

\section{$\rightarrow$ What this article adds:}

Our findings have shown that $31 \%$ of all military trainees with respiratory infection were associated with different viral agents. Human rhinovirus (7.2\%), human respiratory syncytial virus A (7.2\%), and influenza B virus $(6 \%)$ were the most frequently detected respiratory viruses in our study, followed by bocavirus $(3 \%)$, influenza A H1N1 $(2.2 \%)$, influenza A $\mathrm{H} 3 \mathrm{~N} 2(1.5 \%)$, human respiratory syncytial virus B $(1.5 \%)$, adenovirus $(1.5 \%)$, and human coronavirus $229 \mathrm{E}(0.7 \%)$. 
course appear to be at increased risk of acquiring and transmitting respiratory infections (1). Every year, a large number of cases of respiratory infections occur in basic military trainees worldwide which the majority of them are resulting from viral infections. Respiratory infections have a tremendous impact on the military population and are responsible for $25-30 \%$ of hospitalization in the U.S. military (2). Affected trainees generally require a sufficient period of recovery which can lead to a longer training duration and a significant higher rate of viral transmission to newer cohorts (3). The higher vulnerability to respiratory disease epidemics observed in military trainees has been attributed to several causes including crowded habitation, demanding physical training program, stressful working environment, and insomnia $(4,5)$.

Numerous previous studies reported that adenoviruses, influenza $\mathrm{A}$ and $\mathrm{B}$, human rhinoviruses, and coronaviruses are the predominant viruses detected in the military population. Outbreaks of adenovirus-associated respiratory disease have been reported globally in the military environments $(3,5-8)$. It has been suggested that adenovirus infection is associated with male gender, as well as direct contact with an infected person with respiratory symptoms 10 days prior to the onset of illness (8). Outbreaks of influenza viruses $\mathrm{A}$ and $\mathrm{B}$ have also been associated with much morbidity and mortality, especially influenza A (H1N1) pdm09 virus infection (9-13). It has been proposed that crowded living quarters, obesity, asthma, and age group (younger than 40 years) are amongst the major risk factors for acquiring influenza infections (14). Human rhinoviruses are the most important causative agents of the common cold and associated with more complicated upper respiratory tract infections $(15,16)$. Approximately, all the human rhinoviruses have been detected in military trainees during respiratory infection (17). It has been also well documented that human rhinoviruses are associated with lower respiratory tract infections $(18,19)$. Nevertheless, there are other viruses associated with respiratory infections which are not well studied in military populations, including respiratory syncytial viruses (20-22), human bocaviruses (23-25), human parainfluenza viruses (26), metapneumoviruses (27), and echoviruses (28).

Until now, there is no study which aimed to investigate the prevalence of viral agents responsible for respiratory infections among the military population in Iran. Using micro-array technology, the objective of our study was to evaluate the molecular epidemiology of 17 viral pathogens causing respiratory infections among 400 military trainees in a large military training camp in Tehran, over a period of time from January to March 2017. The data resulted from this study can be employed to take preventive measures aimed to reduce the disease burden and prevent future outbreaks.

\section{Methods}

\section{Study population and samples collection}

Study participants were symptomatic military trainees in the basic military training camp of the General Staff of the Armed Forces of the Islamic Republic of Iran. All trainees with symptoms of respiratory tract infection including oral temperature of $\geq 38^{\circ} \mathrm{C}$, cough, sore throat, rhinorrhea, etc. referred to the military medical clinic center were included in this study. Exclusion criteria were a prior history of chronic respiratory disease such as asthma and chronic obstructive pulmonary disease (COPD), recent antiviral therapy, and military personnel. Those trainees meeting the case definition received a written and verbal briefing and were invited to give voluntary and informed consent to participate. This cross-sectional study was designed to enroll 400 subjects over a period of 3 months, from January to March 2017. This study has been approved by the Ethics Committee of Iran University of Medical Sciences under the Ethics Code IR.IUMS.REC1394.26051. Throat or nasopharyngeal swab specimens of patients were collected by Dacron swabs, placed in viral transport media and stored at $-70^{\circ} \mathrm{C}$ until use.

\section{Nucleic acid extraction}

Nucleic acid (DNA/RNA) extraction was performed with $200 \mu$ l of each collected specimen using the ZP02003 MagPurix Viral Nucleic Acid Extraction Kit (Zinexts Life Science Corp, New Taipei, Taiwan) by the MagPurix 12 Series (Zinexts Life Science Corp, New Taipei, Taiwan) consists of compact bench-top robotic workstations for automated, according to the manufacturer's protocol. Total nucleic acids concentration and purity were evaluated using the Nanodrop 2000 spectrophotometer (Thermo Scientific, USA), and subsequently stored at $-70^{\circ} \mathrm{C}$ until further analysis.

\section{Microarray processing}

CLART $^{\circledR}$ PneumoVir array system (Genomica, Coslada, Madrid, Spain) was used to identify genomic sequences of human respiratory viruses, according to the manufacturer's recommendations. Influenza viruses (A, B, and $\mathrm{C}$ ), human parainfluenza viruses 1-4 (subtypes $A$ and $B$ ), respiratory syncytial virus (types $\mathrm{A}$ and $\mathrm{B}$ ), human rhinovirus, metapneumovirus (subtypes A and B), echovirus, adenovirus, human coronavirus $229 \mathrm{E}$, and bocavirus have been investigated by this technique.

This system was based on reverse transcription polymerase chain reaction (RT-PCR) for amplifying a specific 120-330 bp target of the viral genome. RT-PCR was performed in two different ready-to-use amplification tubes. Amplified products were labeled with biotin in the course of the process. After the amplification, biotin-labeled products were hybridized with their respective specific probes immobilized at different sites in the array. Next, the samples were incubated with the streptavidinperoxidase to generate insoluble products which precipitate at the hybridization sites in the array. Hybridization happened in a low-density microarray containing triplicate probes specific to viruses.

\section{Statistical methods}

Statistical analysis was performed using IBM SPSS version 18 (Inc., Chicago, USA) and Microsoft Office 2013 (Excel). Descriptive analysis was carried out using percentage and simple frequencies. Data was reported as count and percentage. Clinical signs and symptoms were 
counted, and the corresponding empirical proportions were calculated with $95 \%$ confidence intervals (CIs) to measure the overall symptom load.

\section{Results}

A total of 400 Iranian military trainees with clinical diagnostic criteria for respiratory infection were enrolled in the survey. All participants were male, with a mean age of $21.69 \pm 4.9$ years (range from 18 to 57 years). Most prevalent complaints of patients referred to the military medical clinic center were sore throat $(\mathrm{n}=302 ; 75.5 \%)$, rhinorrhea $(n=253 ; 63.2 \%)$, cough $(n=237 ; 59.2 \%)$, fever $(n=237$; $59.2 \%)$, and nasal congestion $(\mathrm{n}=202 ; 50.5 \%)$ (Fig. 1). Of the 400 samples, $124(31 \%)$ were positive for respiratory viruses. Human rhinovirus $(n=29 ; 7.2 \%)$, human respiratory syncytial virus A $(n=29 ; 7.2 \%)$, and influenza $B$ virus $(n=24 ; 6 \%)$ were the most frequently detected respiratory viruses in our study, followed by bocavirus $(n=12 ; 3 \%)$, influenza A H1N1 (n=9; 2.2\%), influenza A H3N2 (n=6; $1.5 \%)$, human respiratory syncytial virus $B(n=6 ; 1.5 \%)$, adenovirus $(\mathrm{n}=6 ; 1.5 \%)$, and human coronavirus $229 \mathrm{E}$ $(\mathrm{n}=3 ; 0.7 \%)$. Other viruses including influenza $\mathrm{C}$ virus, human parainfluenza viruses, metapneumovirus, and echovirus have not been detected in any of the samples (Table 1, Fig. 2). It's worth noting that no co-infections were detected in our study. The most cases of dyspnea

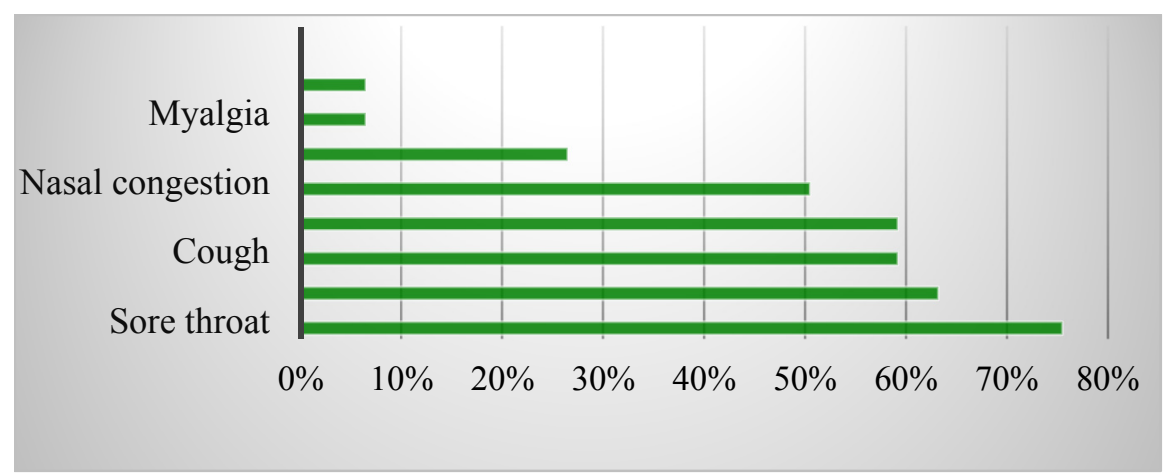

Fig. 1. Frequency distribution of clinical symptoms of respiratory infection among 400 military trainees enrolled in the study

Table 1. Viral etiology and clinical characteristics of military trainees with respiratory tract infection

\begin{tabular}{|c|c|c|c|}
\hline Viral etiology & Number of positive cases (n) & Percent $(\%)$ with $95 \%$ confidence interval & Clinical symptoms $(\mathrm{n})$ \\
\hline Rhinovirus & 29 & $7.2(5-10)$ & $\begin{array}{c}\text { Sore throat (29) } \\
\text { Rhinorrhea (28) } \\
\text { Nasal congestion (25) } \\
\text { Cough (20) } \\
\text { Headache (15) } \\
\text { Fever (10) }\end{array}$ \\
\hline $\begin{array}{l}\text { Respiratory syncytial } \\
\text { virus A }\end{array}$ & 29 & $7.2(5-10)$ & $\begin{array}{c}\text { Cough (27) } \\
\text { Rhinorrhea (26) } \\
\text { Nasal congestion (25) } \\
\text { Sore throat (22) } \\
\text { Fever (20) } \\
\text { Dyspnea (4) }\end{array}$ \\
\hline $\begin{array}{l}\text { Respiratory syncytial } \\
\text { virus B }\end{array}$ & 6 & $1.5(0.6-3.4)$ & $\begin{array}{c}\text { Nasal congestion (4) } \\
\text { Sore throat (4) } \\
\text { Fever (3) } \\
\text { Cough (3) } \\
\text { Rhinorrhea (3) } \\
\text { Dyspnea (1) }\end{array}$ \\
\hline Influenza B & 24 & $6(4-8.9)$ & $\begin{array}{c}\text { Fever }(21) \\
\text { Sore throat }(20) \\
\text { Headache }(16) \\
\text { Rhinorrhea (13) } \\
\text { Cough (8) } \\
\text { Myalgia (5) } \\
\text { Nasal congestion (3) } \\
\text { Dyspnea (2) }\end{array}$ \\
\hline Influenza A H1N1 & 9 & $2.2(1.1-4.4)$ & $\begin{array}{c}\text { Fever (6) } \\
\text { Sore throat (5) } \\
\text { Cough (3) } \\
\text { Myalgia (3) } \\
\text { Headache (2) } \\
\text { Rhinorrhea (2) } \\
\text { Nasal congestion (2) }\end{array}$ \\
\hline Influenza A H3N2 & 6 & $1.5(0.61-3.4)$ & $\begin{array}{c}\text { Fever (4) } \\
\text { Sore throat (2) } \\
\text { Cough (2) } \\
\text { Nasal congestion (1) } \\
\text { Rhinorrhea (1) }\end{array}$ \\
\hline
\end{tabular}




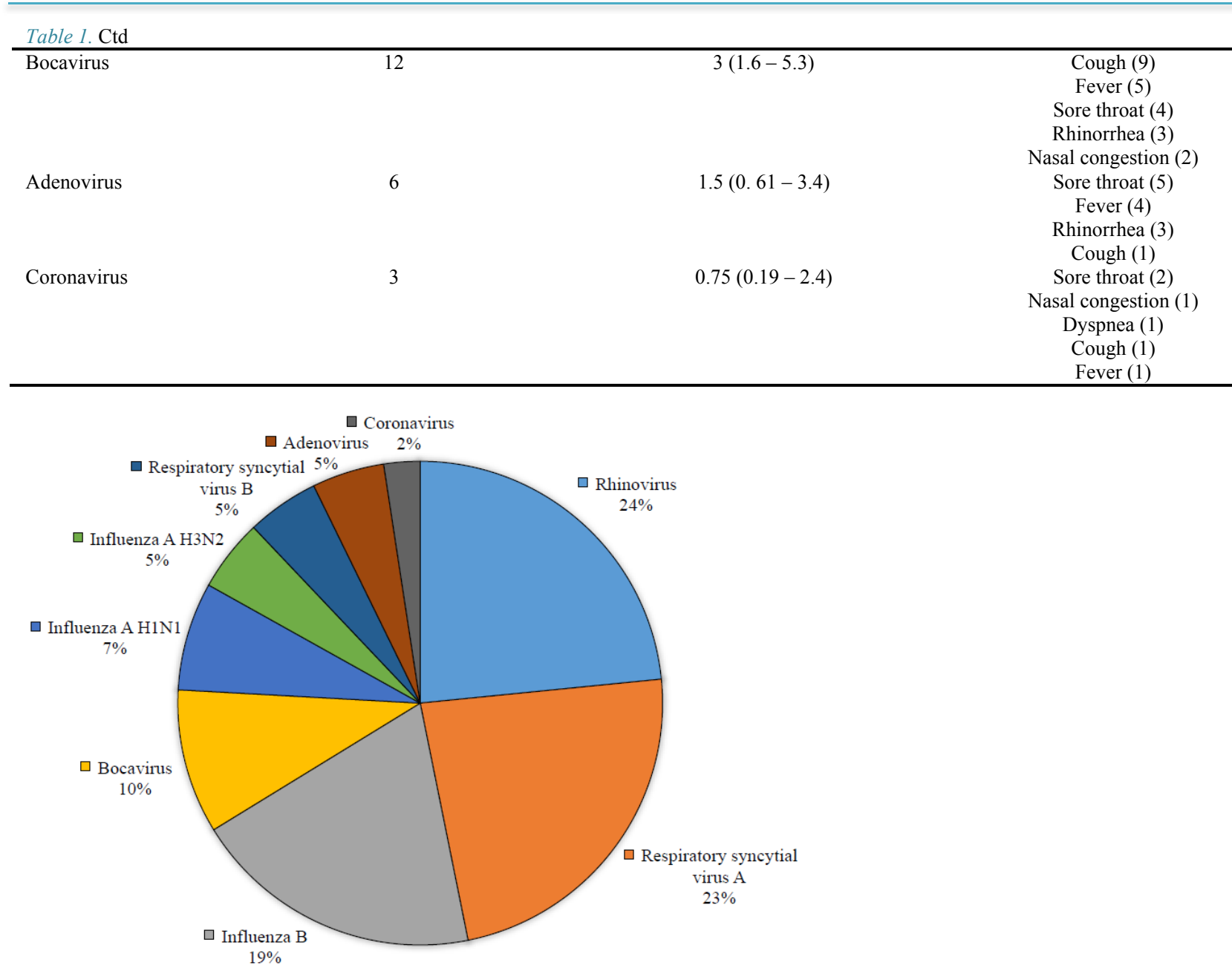

Fig. 2. Viral etiology of respiratory infection in military trainees (among 124 laboratory-confirmed cases of viruses)

$(n=5 ; 62.5 \%)$ were in the group of patients with respiratory syncytial viruses $\mathrm{A}$ and $\mathrm{B}$, followed by influenza $\mathrm{B}$ $(n=2 ; 25 \%)$ and coronavirus $229 \mathrm{E}(\mathrm{n}=1 ; 12.5 \%)$. Sore throat and rhinorrhea were the most frequent symptoms in rhinovirus infection. The most cases of myalgia were seen in influenza $B(n=5 ; 62.5 \%)$ and influenza A H1N1 $(n=3$; $37.5 \%$ ) infections, respectively (Table 1 ).

\section{Discussion}

CLART ${ }^{\circledR}$ Pneumovir array is a qualitative, highly sensitive and high-throughput technology which allows rapid detection of a broad spectrum of human respiratory viruses at a time, particularly to detect viruses that which are not culturable in the laboratory, and also those that are not detectable by the standard multiplex RT-PCR $(29,30)$. In the present study, CLART ${ }^{\circledR}$ Pneumovir array was used to detect 17 common respiratory viruses on 400 throat or nasopharyngeal swab specimens of Iranian military trainees which were collected during January to March 2017. Our findings have shown that $31 \%$ of all patients with respiratory infection were associated with different viral agents. According to our results, rhinovirus, respiratory syncytial virus $A$, and influenza $B$ virus have been responsible for $\sim 66 \%$ of viral respiratory infections among military trainees.
Previous studies have shown that adenoviruses, influenza A and B viruses, human coronaviruses, rhinoviruses, and at lower frequencies, respiratory syncytial viruses and human parainfluenza viruses are the most common viruses leading to respiratory infection in the military environment worldwide $(1,31)$. Similar to our results, respiratory syncytial virus was the main causative agent of acute febrile illness in the Republic of Korea Air Force boot camp from May to July 2011 (32). O'Shea et al. showed that among 54 British military recruits receiving basic training with respiratory symptoms, adenovirus, influenza viruses and respiratory syncytial virus were found in $35 \%, 19 \%$ and $14 \%$, respectively (33). It is notable that among influenza viruses, influenza B was more associated with symptomatic infections, which was consistent with our findings. In a large study in the Singapore military population (13), viral etiology of respiratory illnesses was investigated among 7733 cases of febrile respiratory illness (FRI) using the multiplex PCR. Their results have indicated that $49 \%$ of cases were positive for viral infection and the most commonly detected viruses among FRI cases were influenza A H1N1(13\%), influenza B (13\%), and coxsackievirus $(9 \%)$.

The low prevalence of viral infections in our study in comparison with the other parts of the world can be at- 
tributed to the existence of natural immunity to respiratory viral infections. The Iranian Muslims have several organized mass gatherings such as Hajj pilgrimage and $\mathrm{Ju}$ mu'ah (Friday prayers), likely leading to transmission of respiratory viruses between people and consequently, developing of natural immunity to them. This hypothesis can be evaluated in seroepidemiological studies.

The overall prevalence of respiratory syncytial virus (types A and B) $(8.7 \%)$ in our study was lower than that found in the previous works $(34,35)$. We believe that the rate of respiratory syncytial virus in our study could be even higher since infection with respiratory syncytial virus in a significant proportion of patients is asymptomatic. In accordance with our findings, some studies also found that although both subtypes are infectious and circulate annually, but subtype A is the main cause of respiratory syncytial virus infection which can cause more severe complications (36). Cough, rhinorrhea, nasal congestion, sore throat, and fever were most frequently symptoms of respiratory syncytial virus infection in our investigated population. It was interesting that the majority of dyspnea cases $(n=5 ; 62.5 \%)$ was seen in respiratory syncytial virus infection in compared with other viral infections.

Our study revealed that influenza viruses (particularly influenza B) also have an important role in causing respiratory viral infection along with respiratory syncytial virus with prevalence rate of $9.7 \%$ among military trainees. Interestingly, despite the lack of adenovirus vaccination program in Iranian military health system, we reported a low rate of adenovirus $(n=6 ; 1.5 \%)$ in military trainees. It may be explained by the fact that influenza infection tends to occur in the winter, while adenovirus infection is more likely to occur in the spring, summer, and fall seasons. In fact, seasons can be used to help the in differential diagnosis of FRI among military trainees. It should be noted that our investigation was only performed during the winter months.

There is no report on the prevalence of respiratory viruses in the military population in Iran and other countries in the Middle East. However, several studies have been performed among the general population. For example, in a cross-sectional study in pediatric patients with respiratory symptoms in Shiraz (37), adenovirus was detected in $22 \%$ of nasopharyngeal swabs samples. In another study by Barati et al., adenovirus was detected in $6.3 \%$ of nasopharyngeal secretions samples from 160 children with upper respiratory tract infection, and cervical adenopathy was the most common symptom in adenovirus infection (38). The higher prevalence of adenovirus infection in children can be explained by the fact that adenovirus shedding is more prolonged in children than the adults.

\section{Conclusion}

This study was an important first attempt to determine the molecular epidemiology and clinical symptoms of respiratory viruses circulating in Iranian military trainees. However, there are some limitations that should be noted. First, samples collection were performed completely during winter. So, the estimated prevalence rates of respiratory viruses in our study may not be representative of the actual value, and it is required to collect more data throughout four seasons of the year. Second, samples collection were conducted only from trainees stationed within one military base. Thus, further multi-center studies with larger sample size are strongly recommended to confirm our findings.

\section{Acknowledgments}

This project was funded by Iran University of Medical Sciences (Grant No. 26051).

\section{Conflict of Interests}

The authors declare that they have no competing interests.

\section{References}

1. O'Shea MK, Wilson D. Respiratory infections in the military. J R Army Med Corps. 2013:jramc-2013-000110.

2. Heo JY, Lee JE, Kim HK, Choe K-W. Acute lower respiratory tract infections in soldiers, South Korea, April 2011-March 2012. Emerg Infect Dis. 2014;20(5):875

3. Russell KL, Hawksworth AW, Ryan MA, Strickler J, Irvine M, Hansen CJ, et al. Vaccine-preventable adenoviral respiratory illness in US military recruits, 1999-2004. Vaccine. 2006;24(15):2835-42.

4. Sanchez JL, Cooper MJ, Myers CA, Cummings JF, Vest KG, Russell $\mathrm{KL}$, et al. Respiratory infections in the US military: recent experience and control. Clin Microbiol Rev. 2015;28(3):743-800.

5. Padin DS, Faix D, Brodine S, Lemus H, Hawksworth A, Putnam S, et al. Retrospective analysis of demographic and clinical factors associated with etiology of febrile respiratory illness among US military basic trainees. BMC Infect Dis. 2014;14(1):576.

6. Potter RN, Cantrell JA, Mallak CT, Gaydos JC. Adenovirusassociated deaths in US military during postvaccination period, 19992010. Emerg Infect Dis. 2012;18(3):507.

7. Russell KL, Broderick MP, Franklin SE, Blyn LB, Freed NE, Moradi $\mathrm{E}$, et al. Transmission dynamics and prospective environmental sampling of adenovirus in a military recruit setting. J Infect Dis. 2006;194(7):877-85.

8. Tate JE, Bunning ML, Lott L, Lu X, Su J, Metzgar D, et al. Outbreak of severe respiratory disease associated with emergent human adenovirus serotype 14 at a US air force training facility in 2007. J Infect Dis. 2009;199(10):1419-26.

9. Duron S, Mayet A, Lienhard F, Haus-Cheymol R, Verret C, Védy S, et al. The French Military influenza surveillance system (MISS): overview of epidemiological and virological results during four influenza seasons--2008-2012. Swiss Med Wkly. 2013;143:w13848.

10. Mayet A, Duron S, Nivoix P, Haus-Cheymol R, Ligier C, Gache K, et al. Novel influenza A (H1N1) outbreak among French armed forces in 2009: results of Military Influenza Surveillance System. Public health. 2011;125(8):494-500.

11. Liu PY, Wang LC, Lin YH, Tsai CA, Shi ZY. Outbreak of influenza $\mathrm{A}$ and $\mathrm{B}$ among military recruits: evidence from viral culture and polymerase chain reaction. $\mathrm{J}$ Microbiol Immunol Infect. 2009;42(2):114-21.

12. Yap J, Tan CH, Cook AR, Loh JP, Tambyah PA, Tan BH, et al. Differing clinical characteristics between influenza strains among young healthy adults in the tropics. BMC Infect Dis. 2012;12(1):12.

13. Tan XQ, Zhao X, Lee VJ, Loh JP, Tan BH, Koh WHV, et al. Respiratory viral pathogens among Singapore military servicemen 2009-2012: epidemiology and clinical characteristics. BMC Infect Dis. 2014;14(1):204.

14. Tarabbo M, Lapa D, Castilletti C, Tommaselli P, Guarducci R, Lucà $\mathrm{G}$, et al. Retrospective investigation of an influenza $\mathrm{A} / \mathrm{H} 1 \mathrm{~N} 1 \mathrm{pdm}$ outbreak in an Italian military ship cruising in the Mediterranean Sea, May-September 2009. PLoS One. 2011;6(1):e15933.

15. Radin JM, Hawksworth AW, Kammerer PE, Balansay M, Raman R, Lindsay SP, et al. Epidemiology of pathogen-specific respiratory infections among three US populations. PLoS One. 2014;9(12):e114871.

16. Lewis-Rogers N, Seger J, Adler FR. Human rhinovirus diversity and 
evolution: how strange the change from major to minor. J Virol. 2017:JVI. 01659-16.

17. Savolainen-Kopra C, Blomqvist S, Kaijalainen S, Jounio U, Juvonen $\mathrm{R}$, Peitso A, et al. All known human rhinovirus species are present in sputum specimens of military recruits during respiratory infection. Viruses. 2009;1(3):1178-89.

18. Aponte FE, Taboada B, Espinoza MA, Arias-Ortiz MA, MongeMartínez J, Rodríguez-Vázquez $\mathrm{R}$, et al. Rhinovirus is an important pathogen in upper and lower respiratory tract infections in Mexican children. Virol J. 2015;12(1):31.

19. Ahn JG, Kim DS, Kim KH. Clinical characteristics and cytokine profiles of children with acute lower respiratory tract infections caused by human rhinovirus. PloS one. 2018;13(7):e0198624.

20. Tahamtan A, Inchley CS, Marzban M, Tavakoli-Yaraki M, Teymoori-Rad M, Nakstad B, et al. The role of microRNAs in respiratory viral infection: friend or foe? Rev Med Virol. 2016;26(6):389-407.

21. Salimi V, Ramezani A, Mirzaei H, Tahamtan A, Faghihloo E, Rezaei F, et al. Evaluation of the expression level of $12 / 15$ lipoxygenase and the related inflammatory factors (CCL5, CCL3) in respiratory syncytial virus infection in mice model. Microbial Pathogen. 2017;109:209-13.

22. Tahamtan A, Samieipoor Y, Nayeri FS, Rahbarimanesh AA, Izadi A, Rashidi-Nezhad A, et al. Effects of cannabinoid receptor type 2 in respiratory syncytial virus infection in human subjects and mice. Virulence. 2018;9(1):217-30.

23. Mortazavi HS, Monavari SH, Molaee H, Keyvani H, Pirkooh AA. Human Bocavirus in Hospitalized Iranian Adults with Respiratory Tract Infections during January-June 2014. J Pure Appl Microbiol. 2015:1-6.

24. Monavari SH, Noorbakhsh S, Mollaie H, Fazlalipour M, Kiasari BA. Human Bocavirus in Iranian children with acute gastroenteritis. Med J Islam Repub Iran. 2013;27(3):127.

25. Tavakoli A, Monavari SH, Mollaei H, Bokharaei-Salim F, Esghaei M, Keyvani H, et al. Frequency of human Parvovirus B19 among patients with respiratory infection in Iran. Med J Islam Repub Iran. 2018;32:38.

26. Maykowski P, Smithgall M, Zachariah P, Oberhardt M, Vargas C, Reed C, et al. Seasonality and clinical impact of human parainfluenza viruses. Influenza Other Respir Viruses. 2018

27. Zhou Jy, Peng Y, Peng Xy, Gao Hc, Sun Yp, Xie Ly, et al. Human bocavirus and human metapneumovirus in hospitalized children with lower respiratory tract illness in Changsha, China. Influenza Other Respir Viruses. 2018;12(2):279-86.

28. Hellferscee O, Tempia S, Walaza S, Variava E, Dawood H, Wolter $\mathrm{N}$, et al. Enterovirus genotypes among patients with severe acute respiratory illness, influenza-like illness, and asymptomatic individuals in South Africa, 2012-2014. J Med Virol. 2017;89(10):1759-67.

29. Frobert E, Escuret V, Javouhey E, Casalegno J-S, BouscambertDuchamp $\mathrm{M}$, Moulinier $\mathrm{C}$, et al. Respiratory viruses in children admitted to hospital intensive care units: evaluating the CLART ${ }^{\circledR}$ Pneumovir DNA array. J Med Virol. 2011;83(1):150-5.

30. Keyvani H, Moghoofei M, Bokharaei-Salim F, Mostafaei S, Mousavi S-AJ, Monavari SH, et al. Prevalence of respiratory viruses in Iranian patients with idiopathic pulmonary fibrosis. J Med Microbiol. 2017;66(11):1602-6.

31. Korzeniewski K, Nitsch-Osuch A, Konior M, Lass A. Respiratory tract infections in the military environment. Respir Physiol Neurobiol. 2015;209:76-80.

32. Park WJ, Yoo SJ, Lee SH, Chung JW, Jang KH, Moon JD. Respiratory Syncytial Virus Outbreak in the Basic Military Training Camp of the Republic of Korea Air Force. J Prev Med Public Health. 2015;48(1):10.

33. O'Shea MK, Pipkin C, Cane PA, Gray GC. Respiratory syncytial virus: an important cause of acute respiratory illness among young adults undergoing military training. Influenza Other Respir Viruses. 2007;1(5-6):193-7.

34. Munywoki PK, Koech DC, Agoti CN, Bett A, Cane PA, Medley $\mathrm{GF}$, et al. Frequent asymptomatic respiratory syncytial virus infections during an epidemic in a rural Kenyan household cohort. J Infect Dis. 2015;212(11):1711-8.

35. Moreira LP, Watanabe ASA, Camargo CN, Melchior TB, Granato C, Bellei N. Respiratory syncytial virus evaluation among asymptomatic and symptomatic subjects in a university hospital in
Sao Paulo, Brazil, in the period of 2009-2013. Influenza Other Respir Viruses. 2018;12(3):326-30.

36. Bracht M, Basevitz D, Cranis M, Paulley R. Impact of Respiratory Syncytial Virus. Drugs in R \& D. 2011;11(3):215-26.

37. Moattari A, Emami A, Pirbonyeh N, Yaghoobi R. Detection of Adenovirus Infection Among Children With Acute Respiratory Disease During 2010-2012 in Shiraz, Iran. Arch Pediatr. 2014;2(2):e15930.

38. Barati M, Noorbakhsh S, Tabatabaei A, Taj FE, Talebi-Taher M. Adenovirus, influenza virus A, B and respiratory syncitial virus infection in children. Int J Infect Dis. 2008;12:e66. 